\title{
Nutritive Quality of Big Bluestem (Andropogon gerardii) and Eastern Gamagrass (Tripsacum dactyloides) Exposed to Tropospheric Ozone
}

\author{
John S. Lewis, ${ }^{1}$ Stephen S. Ditchkoff, ${ }^{1}$ John C. Lin, ${ }^{2}$ \\ Russell B. Muntifering, ${ }^{2}$ and Arthur H. Chappelka ${ }^{1}$ \\ ${ }^{1}$ School of Forestry and Wildife Sciences, Auburn University, Auburn, AL 36849; and \\ ${ }^{2}$ Department of Animal Sciences, Auburn University, Auburn, AL 36849
}

\begin{abstract}
Tropospheric ozone $\left(\mathrm{O}_{3}\right)$ is a phytotoxic air pollutant widespread in industrialized nations of the world. Ozone is produced by the photo-oxidation of hydrocarbons released into the atmosphere by combustion of fossil fuels. Studies demonstrate $\mathrm{O}_{3}$ can be transported from metropolitan areas to rural areas important to agricultural and forestry practices. Reports regarding $\mathrm{O}_{3}$ effects have focused on vegetation important to food production or agronomic crops of economic importance. However, relatively little is known about $\mathrm{O}_{3}$ effects on native plant species. The effects of tropospheric $\mathrm{O}_{3}$ on two warm-season grasses, eastern gamagrass (Tripsacum dactyloides L.) and big bluestem (Andropogon gerardii Vitman), were examined during June-September of 2003. Plants were fumigated with three levels of $\mathrm{O}_{3}$ in a randomized-block experiment with three replicates of each treatment. Grasses were grown in open-top chambers with introduced carbon-filtered (CF) air, characteristic of clean air quality; non-filtered $(\mathrm{NF})$ air, representative of quality in Auburn, AL; and air with double $(2 \times)$ the ambient concentration of $\mathrm{O}_{3}$. Because forage quality can be as important as quantity, we determined various effects on nutritive quality characteristics in addition to biomass yield. Big bluestem exhibited little response to $\mathrm{O}_{3}$ exposure. For eastern gamagrass, we generally found decreased nutritive quality with increasing $\mathrm{O}_{3}$ exposure as evidenced by increased concentrations of cell wall constituents and decreased concentrations of $\mathrm{N}$. Regrowth of both species exhibited little treatment effect which emphasizes the importance of timing and duration of $\mathrm{O}_{3}$ exposures in relation to physiological stage of plant development. Decreased nutritive quality parameters observed for eastern gamagrass may have implications to diet selection and nutrient intake by ruminant herbivores. In addition, range managers can use species-specific information regarding $\mathrm{O}_{3}$ sensitivity to make decisions about mechanical harvesting and grazing regimes of these forages growing in areas exposed to elevated $\mathrm{O}_{3}$ concentrations.
\end{abstract}

\section{Resumen}

El ozono toposférico $\left(\mathrm{O}_{3}\right)$ es un contaminante del aire fitotóxico ampliamente diseminado en los países industrializados del mundo. El ozono se produce por la fotooxidación de los hidrocarbonos liberados en la atmósfera por la combustión de combustibles fósiles. Los estudios muestran que el $\mathrm{O}_{3}$ puede ser transportado de las áreas metropolitanas a las áreas rurales importantes agrícola y forestalmente. Los reportes respecto $\mathrm{al} \mathrm{O}_{3}$ se han enfocado en la vegetación importante para la producción de alimentos o cultivos agrícolas de importancia económica. Sin embargo, poco se sabe de los efectos del $\mathrm{O}_{3}$ en las plantas de especies nativas. De Junio a Septiembre del 2003 se examinaron los efectos del $\mathrm{O}_{3}$ en dos especies de zacates de estación caliente "Eastern gamagrass" (Tripsacum dactyloides L.) y "Big bluestem" (Andropogon gerardii Vitman). Las plantas fueron fumigadas con tres niveles de $\mathrm{O}_{3}$ en un experimento de bloques al azar con tres repeticiones por tratamiento. Los zacates crecieron en cámaras abiertas de la parte superior con aire circulado a través de un filtro de carbón (CF) aire limpio; aire no filtrado (NF), representativo de la calidad del aire de Auburn, AL y aire con el doble de la concentración ambiental de $\mathrm{O}_{3}$. Debido a que la calidad del forraje puede ser tan importante como la cantidad, determinamos los efectos en la calidad nutritiva, además del rendimiento de biomasa. El "Big bluestem mostró poca respuesta a la exposición de $\mathrm{O}_{3}$. En el "Eastern gamagrass" generalmente encontramos una disminución de la calidad nutritiva al incrementar la exposición al $\mathrm{O}_{3}$, evidenciado por el aumento de la concentración de los constituyentes de la pared celular y un disminución en las concentraciones de N. El rebrote de ambas especies mostró pocos efectos de los tratamientos, lo cual enfatiza la importancia de la época y duración de la exposición $\mathrm{al}_{3}$ en relación al estado fisiológico de desarrollo de la planta. La disminución observada en los parámetros de calidad del "Eastern gamagrass" puede tener implicaciones en la selección de la dieta y consumo de nutrientes de los rumiantes. Además, los manejadores de pastizales pueden usar información especifica de especies en relación a su sensitividad al $\mathrm{O}_{3}$ para tomar decisiones respecto regimenes de cosecha mecánica y apacentamiento de estos forrajes creciendo en áreas con altas concentraciones de $\mathrm{O}_{3}$.

Key Words: forage quality, native warm-season grasses, nutrition, open-top chamber, ozone sensitivity

Research was funded by the Auburn University Environmental Institute.

Correspondence: John S. Lewis, Caesar Kleberg Wildlife Research Institute, 700 University Blvd, MSC 218, Kingsville, TX 78363-8202. Email: john.lewis@tamuk.edu

Manuscript received 14 February 2005; manuscript accepted 14 March 2006. 


\section{INTRODUCTION}

Tropospheric ozone $\left(\mathrm{O}_{3}\right)$ is a widespread phytotoxic air pollutant found in all industrialized nations of the world (Chameides et al. 1994). It is created by the photo-oxidation of hydrocarbons and nitrogen oxides that result from combustion processes associated with automobiles, industry, power plants, and other sources of high-temperature combustion of fossil fuels (NCEA 1996). Predictive models indicate that worldwide $\mathrm{O}_{3}$ concentrations, if left unchecked, will increase at a rate of $\sim 0.5 \%$ to $2 \% /$ year over the next 50 years (Vingarzan 2004). Once thought to be confined to metropolitan areas, $\mathrm{O}_{3}$ is now known to be transported far from industrial centers to rural areas where much of the world's agricultural and forested lands are exposed to harmful levels of $\mathrm{O}_{3}$ (Chameides et al. 1994).

During the past two decades (1980-2000), overall $\mathrm{O}_{3}$ concentrations in the US decreased slightly, based on the former 1-hour and the new 8-hour air quality standards (US EPA 2001). However, not all areas of the country have experienced improvement in air quality. In the southern and north-central regions of the US, ambient $\mathrm{O}_{3}$ levels increased during the 1990s (US EPA 2001). This increase is due to several factors including increased urbanization, favorable climate and dense vegetative cover, which is the main source of organic hydrocarbons (e.g., isoprene) that are precursors for $\mathrm{O}_{3}$ production (Chameides and Cowling 1995).

Rural locales in the South occasionally experience $\mathrm{O}_{3}$ episodes above $100 \mathrm{ppb}\left(\mathrm{nl} \mathrm{l}^{-1}\right)$, with typical summer daytime levels (0900-1600 hr) averaging > $50 \mathrm{ppb}$ (Chameides and Cowling 1995). There are approximately 100 counties in the South currently classified in non-attainment of the 8-hour National Air Quality Standard for $\mathrm{O}_{3}$ (US EPA 2001). Due to the regional nature of $\mathrm{O}_{3}$, ecological effects (reductions in growth, productivity, visible injury, etc.) are not limited to these areas, and have been observed in many other localities currently meeting attainment of the most recent US EPA standard (Chappelka and Wergowske 1994; Chappelka and Samuelson 1998).

The physiological and chemical responses of vegetation elicited by exposure to elevated $\mathrm{O}_{3}$ are varied. Ozone can affect plant tissues, resource acquisition, and nutrient distribution that collectively can reduce biomass yield (Krupa and Manning 1988; Kängasjarvi et al. 1994) and cause economic impacts in the millions of dollars (Adams et al. 1988; Adams et al. 1989). Because of their economic importance, $\mathrm{O}_{3}$ injury to yield and nutritive quality of grain crops and other food crops has been studied extensively. However, only recently has research been directed towards understanding effects of $\mathrm{O}_{3}$ on nutritive quality of forage species in relation to ruminant herbivory (Krupa et al. 2004).

Available data indicate that, within the range of ambient $\mathrm{O}_{3}$ concentrations typically observed in many areas of the US and Europe, forage biomass from managed cool-season grasslands can be decreased on average by approximately $10 \%$ (Fuhrer 1997). Muntifering et al. (2000) and Powell et al. (2003) have reported that, based on altered plant cell wall chemistry in select warm-season forages, decreases in nutritive quality (for ruminant herbivores) due to $\mathrm{O}_{3}$ injury could be expected to approach the same order of magnitude as that observed for losses in biomass yield.
Integration of nutritive quality assessment with information on biomass yield is necessary to more fully characterize potential impacts of $\mathrm{O}_{3}$ on system total productivity (Krupa et al. 2004). If these concepts from managed agricultural systems can be extended and validated experimentally for native grassland and related managed ecosystems, implications regarding plantherbivore interactions could be enormous.

Production of crops, food animals, wildlife, and forests on the same land base is receiving considerable interest worldwide. Integrating multiple resources in this way has become a possible solution to the challenge of sustaining forests as a resource for wood products and an instrument of conservation while simultaneously providing more land for increased food production (Byington and Child 1981). Therefore, understanding how anthropogenic disturbances, including $\mathrm{O}_{3}$, influence these ecosystems is of great importance.

We investigated two native, warm-season grass species commonly planted for both their wildlife value and usefulness as forages for livestock production. Big bluestem (Andropogon gerardii Vitman) and eastern gamagrass (Tripsacum dactyloides L.) were exposed to three levels of $\mathrm{O}_{3}$ to quantify the impact of this pollutant on nutritive quality of these species. Our specific objectives were to determine whether exposure to elevated levels of $\mathrm{O}_{3}$ influences 1) nutritive quality and 2) above-ground biomass yield of big bluestem and eastern gamagrass. We hypothesized that nutritive quality and above-ground biomass of both big bluestem and eastern gamagrass would be associated negatively with ground-level ozone.

\section{METHODS}

\section{Species Description}

Eastern gamagrass and big bluestem are native perennial bunchgrasses; however, little is known about their sensitivity to elevated $\mathrm{O}_{3}$ concentrations. Warm-season grasses such as these have increased in popularity with government agencies that are now using them in restoration and conservation programs such as the Wildlife Habitat Incentive Program, Wetland Reserve Program, and the Environmental Quality Incentives Program (Best et al. 1997). Additional uses of native bunchgrasses include applications such as erosion prevention and nutrient absorption in riparian areas (Ball et al. 2002). Giuliano (2002) has shown that integration of warm-season grasses in a managed pasture setting increased diversity and richness of avian species in those fields. Additionally, these grasses are used to support livestock production because palatability and nutritive quality are high during the summer growing season when cool-season grasses such as fescue are at lower levels of production (Stubbendieck et al. 1997; Ball et al. 2002). Consequently, many farmers and range managers are using these perennial forages for livestock production.

\section{$\mathbf{O}_{3}$ Exposure System}

The $\mathrm{O}_{3}$ exposure system used in this study was maintained on a 1.5-ha fenced area on the Auburn University campus (lat $32^{\circ} 36^{\prime} \mathrm{N}$, long $\left.85^{\circ} 30^{\prime} \mathrm{W}\right)$ in Lee County, Alabama. The exposure system consisted of nine open-top chambers (OTC), each $4.8 \mathrm{~m}$ high and $4.5 \mathrm{~m}$ in diameter. Each aluminum-framed chamber was surrounded with clear plastic which was double- 
layered and perforated at the bottom for introduction of air by fans (Heagle et al. 1989). The floor of each chamber was sprayed with glyphosate (Roundup ${ }^{\circledR}$ ) and mulched with straw to reduce weed growth. Both grass species were seeded in 130 $\mathrm{cm}^{3}$ cone-tainers during 16-21 April 2003 at the Plant Sciences Research Center greenhouse, a facility of the Alabama Agricultural Experiment Station located on the Auburn University campus approximately $1 \mathrm{~km}$ from the $\mathrm{O}_{3}$ treatment site. Plants were thinned to two plants per cone-tainer on 6 May and then to one plant per cone-tainer on 20 May. Plants were watered daily and fertilized once after the final thinning with a commercial fertilizer $\left(4.5 \mathrm{~g} 15: 16: 17\right.$ of $\mathrm{N}: \mathrm{P}_{2} \mathrm{O}_{5}: \mathrm{K}_{2} \mathrm{O}$ per $3.8 \mathrm{~L}$ of water). Plants were transferred to pots $(5.68 \mathrm{~L})$ filled with a Norfolk sandy loam soil (Fine-loamy, kaolinitic, thermic, Typic Kankiudults) on 2 June. Fifteen pots of each species were placed in each chamber and arranged by species into 2 triangular sections of equal surface area. Plants were allowed to acclimate to chambers for 1 week prior to the beginning of fumigation on 9 June at which point plants were at $\sim 55$ days of growth. Throughout the experiment plants were irrigated twice daily $(1100$ and $1600 \mathrm{~h}$ ) for 10 minutes per watering episode regardless of ambient rainfall. Plants were fertilized once during the acclimation period with $3 \mathrm{~g}$ of controlled-release fertilizer (14:14:14 of $\left.\mathrm{N}: \mathrm{P}_{2} \mathrm{O}_{5}: \mathrm{K}_{2} \mathrm{O}\right)$. Ozone was generated by passing pure oxygen $\left(\mathrm{O}_{2}\right)$ through a high-intensity electrical discharge source (Griffin Inc., Lodi, NJ) and applied to the chambers $12 \mathrm{~h} \mathrm{~d}^{-1}(0900-2100 \mathrm{~h}), 7 \mathrm{~d} \mathrm{wk}^{-1}$. Fans were turned off from 2300-0500 hours to permit natural dew formation within the chambers. Ozone concentrations were monitored using an US EPA approved instrument (Thermo Environ. Instr., Inc., Hopkinton, MA). Monitoring is time-shared so that each monitoring port is read 2 times per hour. Instruments were periodically calibrated according to US EPA quality assurance guidelines.

\section{Study Design}

To determine how $\mathrm{O}_{3}$ affected the nutritive quality of our forages, we fumigated plants with 3 different $\mathrm{O}_{3}$ levels from 9 June until 4 September 2003. Treatments were carbon-filtered air (CF; $n=3)$, ambient, non-filtered air (NF; $n=3)$, and two times ambient $\mathrm{O}_{3}$ conditions $(2 \times ; n=3)$. The CF treatment removed $\sim 50 \%$ of the ambient ozone, reducing levels to 14-16 ppb, representing a pristine environment (Lefohn et al. 1990). Ambient air conditions in Auburn of $\sim 30-50 \mathrm{ppb}$ with occasional episodes above $80-100 \mathrm{ppb}$ (A.H. Chappelka, personal communication, 2003) are consistent with current rural ozone averages in agricultural and forested areas of the southeastern US (US EPA 2001). The $2 \times$ treatment approximates a doubling of ambient $\mathrm{O}_{3}$ levels, and is representative of concentrations observed in the vicinity of large metropolitan areas in the southern US, such as Atlanta and Birmingham (Chameides and Cowling 1995).

Five plants of each species were harvested at each of 3 harvest dates from each of the 9 chambers. In a few cases, we could only harvest 4 plants per chamber due to mortality. Three primary harvests (P1, 8 July; P2, 7 Aug.; P3, 4 Sept.) and 2 regrowth harvests (R1, 8 Aug.; R2, 5 Sept.) were performed at approximately 4,8 , and 12 weeks following start of fumigation (early, mid-, and late season). Regrowth forage was harvested twice (at 8 and 12 weeks following start of fumigation) from
Table 1. Mean monthly temperature and precipitation for JuneSeptember 2003 and 30-y averages for Auburn, AL (Data source: National Climatic Data Center; http://www.ncdc.noaa.gov/oa/ncdc.html).

\begin{tabular}{lccccc}
\hline & \multicolumn{2}{c}{ Air temperature $\left({ }^{\circ} \mathrm{C}\right)$} & & \multicolumn{2}{c}{ Precipitation $(\mathrm{cm})$} \\
\cline { 2 - 3 } \cline { 5 - 6 } Month & 2003 & 30 -y average & & 2003 & 30-y average \\
\hline June & 24.4 & 25.1 & & 21.8 & 10.1 \\
July & 25.5 & 26.6 & & 26.5 & 14.6 \\
August & 26.1 & 26.3 & & 13.5 & 7.7 \\
September & 22.7 & 23.7 & & 7.7 & 9.4 \\
\hline
\end{tabular}

the same plants that were harvested after 4 weeks (P1) of fumigation. Each plant was harvested at $\sim 15 \mathrm{~cm}$ above ground to represent biomass available to a moderately aggressive grazing or harvest regime.

Harvested material was oven-dried at $50^{\circ} \mathrm{C}$ to a constant weight and biomass was recorded. Plants from each chamber were then pooled and were ground in a Wiley mill to pass a $1 \mathrm{~mm}$ screen. Forage cell wall constituents were sequentially fractionated to neutral detergent fiber (NDF), acid detergent fiber (ADF), and lignin according to procedures of Van Soest et al. (1991) using an ANKOM fiber analyzer (ANKOM Technology Corporation, Fairport, NY). Crude protein (CP) concentrations of forage samples was determined using the Kjeldahl procedure (Kjeldahl $\mathrm{N} \times 6.25)($ AOAC 1995), and dry matter (DM) was analyzed according to the Association of Analytical Chemists (1995). Relative feed value (RFV) (Rohweder et al. 1978) was calculated from concentrations of NDF and ADF using prediction equations of Linn and Martin (1989). RFV is a quality indicator which integrates DM intake and digestibility into a single index, and, when used in conjunction with protein concentration, may be used in pricing hay (Rohweder et al. 1978; Linn and Martin 1989).

\section{Statistical Analysis}

The experimental design was a completely randomized splitplot where species is the split-plot and OTC is the main-plot factor. For analysis of variance (ANOVA) of primary-growth forage data we used PROC GLM (SAS 1990), with OTC within treatments as the error term for treatment main effects. Residual mean square was the error term for harvest period (subplot) and period $\times$ treatment interaction. When appropriate, we used multiple comparison tests (PROC GLM, least squares means, Tukey adjustment) to determine differences among treatments within each period and differences among periods within each treatment. Because of physiological changes in growth habit initiated by the first cutting, data from regrowth forages were tested separately from P1 forage, using the REPEATED command in PROC GLM.

\section{RESULTS}

\section{Meteorological Data}

Mean monthly temperatures for June-September 2003 tended to be lower $\left(-0.72^{\circ} \mathrm{C}\right.$ June, $-1.1^{\circ} \mathrm{C}$ July, $-0.27^{\circ} \mathrm{C}$ Aug, $-1.00^{\circ} \mathrm{C}$ Sept.) than the 30-year monthly averages (19712000) for the study area (Table 1). Mean monthly rainfall exceeded 30-year averages by $11.73 \mathrm{~cm}, 11.99 \mathrm{~cm}$, and $5.82 \mathrm{~cm}$ 


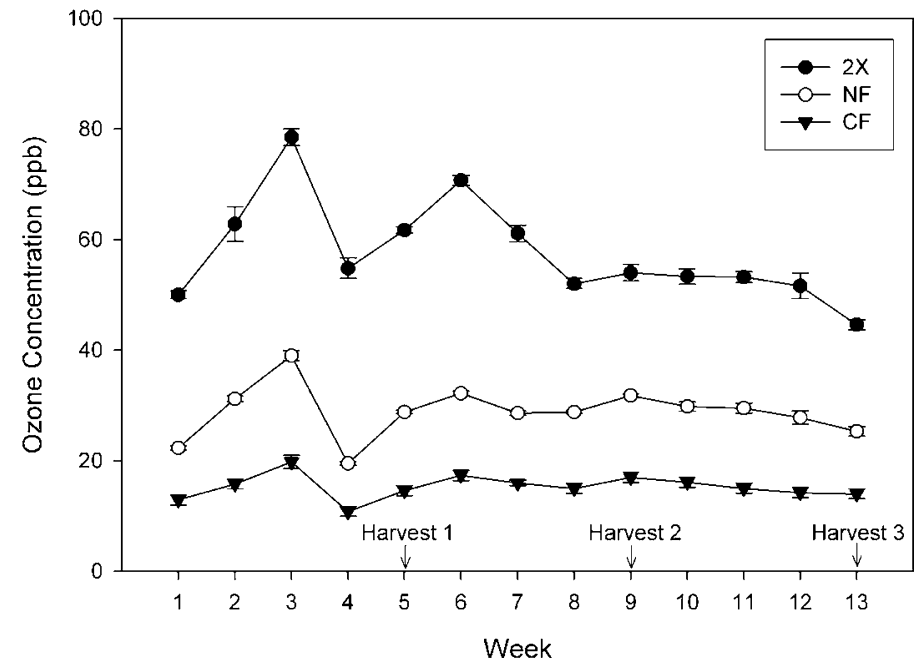

Figure 1. Weekly 12-hr $\mathrm{O}_{3}$ concentrations of 3 treatment levels (carbonfiltered, non-filtered, and $2 \times$ ambient $\mathrm{O}_{3}$ conditions) for 9 June-4 September, 2003, with dates of 3 harvests of both eastern gamagrass (Tripsacum dactyloides) and big bluestem (Andropogon gerardii). Bars represent standard error.

for June, July, and August, respectively. September was $1.75 \mathrm{~cm}$ below average in rainfall. Mean 12-hr (0900-2100 hr) $\mathrm{O}_{3}$ concentrations over the entire experiment were 14, 29, and 61 $\mathrm{ppb}$, respectively, for $\mathrm{CF}, \mathrm{NF}$, and $2 \times$ treatments (Fig. 1). Within period 1 , hourly peak $\mathrm{O}_{3}$ exposures were 43,71 , and $169 \mathrm{ppb}$ for CF-, NF-, and $2 \times$-treated plants. CF, NF, and $2 \times$ hourly $\mathrm{O}_{3}$ peaks occurred at 45, 51, and $112 \mathrm{ppb}$, respectively, for period 2. Within period 3, hourly peak exposures were 50, 60 , and $113 \mathrm{ppb}$ for CF, NF, and $2 \times$, respectively.

\section{Eastern Gamagrass}

Both biomass and crude protein were significantly influenced by period of harvest (Table 2). For all treatments, biomass yield increased by $1266-1433 \%$ from period $1-3$ and CP decreased by $48-66 \%$ during periods $1-3$. While we found no differences among treatments for concentration of CP within any period, we did observe that plants treated with $2 \times \mathrm{O}_{3}$ had greater biomass than those exposed to CF air during periods 2 and 3 (Table 3).

We found period $\times$ treatment interactions for concentrations of NDF, ADF, and lignin, and for RFV. Within period 3 greater concentrations of NDF $(12.97 \%)$, ADF $(14.61 \%)$, and lignin $(48.52 \%)$ were observed for $2 \times$ plants compared with
CF plants: there were no differences among periods 1 and 2 . There was a general tendency for NDF and ADF to increase from periods $1-3$, and for lignin to decrease from periods $1-3$ for most treatments. RFV was less $(16.74 \%)$ for $2 \times$ plants than CF plants within period 3 and decreased among all treatments as time progressed.

There was an overall treatment effect $\left(F_{2,6}=5.34\right.$; $P=0.047)$ for regrowth of biomass for eastern gamagrass (Table 4). However, examining treatments separately, biomass tended to decline $(29.78-37.68 \%$ ) for $2 \times$ and NF plants, but CF plants did not show a similar decline. We found no treatment effect $(P \geq 0.050)$ for any other response variable measured for regrowth of eastern gamagrass.

\section{Big Bluestem}

Period of harvest had a significant effect on primary growth of big bluestem for all variables measured (Table 5). Biomass increased by $2345 \%$ for NF and by $1727 \%$ for CF plants, but not $2 \times$-treated plants (Table 6). CP decreased by $48.15-$ $60.16 \%$ among all treatments from period $1-3$. We detected no differences for NDF concentrations among any treatments. ADF concentration of CF plants was $28.39 \%$ greater for period 3 than period 1. Lignin concentrations increased $102.14 \%$ between periods 2-3 for CF plants, but increases were not significant for $2 \times$ and NF plants. RFV tended to decline (11.46-17.99\%) among treatments from period $1-3$, but multiple comparisons yielded no differences among periods for any treatment.

There was a period effect $\left(F_{1,6}=7.15 ; P=0.037\right)$ for RFV of big bluestem regrowth. Marginal period effects were detected for concentration of $\operatorname{NDF}\left(F_{1,6}=5.52 ; P=0.057\right)$. However, we found no treatment effect $(P \geq 0.050)$ for any response variables measured for regrowth of big bluestem.

\section{DISCUSSION}

Ozone concentrations throughout the 2003 growing season were lower than previously reported (Muntifering et al. 2000; Powell et al. 2003) for our study area, yet treatment effects were still observed for eastern gamagrass. We generally found increased concentrations of cell wall constituents (ADF, NDF, and lignin), decreased concentration of CP, and decreased RFV as exposure time increased. While period effects for concentrations of cell wall constituents, crude protein, and of biomass yield were expected as a result of natural plant development, analysis within periods revealed noteworthy differences among

Table 2. Period, treatment, and period $\times$ treatment main effects for eastern gamagrass (Tripsacum dactyloides) primary growth exposed to 3 ozone concentrations from 9 June-4 September 2003 and harvested during 3 periods at 30-d intervals.

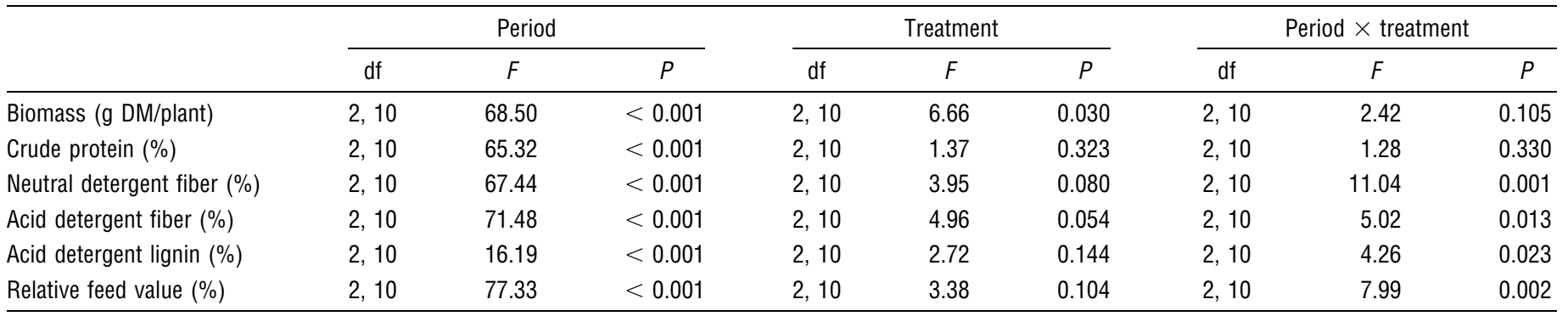


treatments for eastern gamagrass. Treatment effects within period 3 were greatest and no general treatment effects within periods 1 and 2 were observed. Within the third period, treatments were significantly different for all variables in eastern gamagrass except $\mathrm{CP}$ concentration. Plants treated with $2 \times \mathrm{O}_{3}$ had elevated NDF, ADF, and lignin concentrations, as well as greater biomass yield than NF and CF-treated forages, while values for RFV and CP concentration were less. The observed decreases in CP concentration and RFV and increases in concentration of cell wall fractions for eastern gamagrass in successive periods are similar to cumulative $\mathrm{O}_{3}$ effects reported for other grass species (Muntifering et al. 2000). However, elevated fiber fraction concentrations and decreased $\mathrm{CP}$ concentration and RFV with greater biomass are a relatively novel finding. Generally, decreases in biomass are observed when $\mathrm{O}_{3}$-sensitive plants are chronically exposed to $\mathrm{O}_{3}$ (Pleijel and Danielsson 1997), and nutritive quality characteristics suffer as a result. Our results suggest that, for eastern gamagrass, nutritive quality can be affected without a concomitant decline in biomass. Increased biomass may be a short-term stress response resulting in increased photosynthate allocation to shoots (Miller 1988), although it is unlikely that this response could be sustained over a longer exposure period. The lack of response for big bluestem may be attributed to relatively low $\mathrm{O}_{3}$ exposures during the 2003 growing season, or big bluestem may be less sensitive to $\mathrm{O}_{3}$ than eastern gamagrass. The period effects observed for big bluestem may be explained by development of tissues (i.e., increase in cell wall constituents) as result of natural plant development (Ball et al. 2002). Few acute exposure events may explain a general lack of treatment difference within periods 1 and 2 . However, the influence of moderate $\mathrm{O}_{3}$ exposures over the treatment period was substantial enough to induce a cumulative response by period 3 for eastern gamagrass.

A number of factors, including stage of plant development, relative humidity, soil moisture, and concentration gradient of $\mathrm{O}_{3}$ (Temple et al. 1985; Heagle et al. 1988; Runeckles and Krupa 1994; Pleijel et al. 1996) interact to determine plant response. Both eastern gamagrass and big bluestem are $\mathrm{C}_{4}$ plants and were expected to have intrinsically lower stomatal conductance compared with $\mathrm{C}_{3}$ plants (Volin et al. 1998). However, by keeping the vegetation well-watered and in a nutrient-rich growth medium, we could have potentially enhanced plant response to $\mathrm{O}_{3}$ by maximizing gas uptake (Muntifering et al. 2000). It has been acknowledged that native plants may vary in response to $\mathrm{O}_{3}$ as a result of environmental changes that alter gas uptake in the leaves (Manning 2003). However, we chose to maintain as many climatic variables as possible to remove confounding factors.

Timing between $\mathrm{O}_{3}$ episodes and physiological stage of development of harvested forages is considered to be critical in extent of injury caused by fumigation. Yield losses in crops such as wheat that are allowed to grow until senescence are generally greater than losses in pastures which are continually cut or grazed (Pleijel et al. 1996). As $\mathrm{O}_{3}$ sensitivity increases with leaf age (Karlsson et al. 1995), it is to be expected that younger leaves will show less of a response to fumigation. Our results showing little treatment effect on regrowth support this idea. We hypothesize that cutting/grazing coupled with harvest timing and frequency can have effects on biomass yield and
Table 3. Nutritive quality values for eastern gamagrass (Tripsacum dactyloides) primary growth exposed to 3 ozone concentrations from 9 June-4 September 2003 and harvested during 3 periods at 30-d intervals.

\begin{tabular}{|c|c|c|c|c|c|c|}
\hline & \multicolumn{2}{|c|}{ Period 1 (30 d) } & \multicolumn{2}{|c|}{ Period $2(60 \mathrm{~d})$} & \multicolumn{2}{|c|}{ Period $3(90 \mathrm{~d})$} \\
\hline & $\bar{x}$ & $\mathrm{SE}^{1}$ & $\bar{x}$ & SE & $\bar{x}$ & SE \\
\hline \multicolumn{7}{|c|}{ Biomass (g DM/plant) } \\
\hline $\mathrm{CF}$ & $0.90 \mathrm{~A}^{2} \mathrm{a}^{3}$ & 0.21 & $7.33 \mathrm{ABa}$ & 3.54 & $13.80 \mathrm{Ba}$ & 1.68 \\
\hline$N F$ & $1.18 \mathrm{Aa}$ & 0.23 & 11.13 Bab & 2.83 & 16.13 Bab & 2.08 \\
\hline $2 \times$ & $1.52 \mathrm{Aa}$ & 0.09 & $17.47 \mathrm{Bb}$ & 2.28 & $23.20 \mathrm{Bb}$ & 1.20 \\
\hline \multicolumn{7}{|c|}{ Crude protein (\%) } \\
\hline CF & $18.87 \mathrm{Aa}$ & 2.01 & $13.29 \mathrm{ABa}$ & 1.27 & $9.78 \mathrm{Ba}$ & 1.65 \\
\hline NF & $20.34 \mathrm{Aa}$ & 0.86 & $10.65 \mathrm{Ba}$ & 0.22 & $7.58 \mathrm{Ba}$ & 0.72 \\
\hline $2 \times$ & $21.49 \mathrm{Aa}$ & 0.27 & $11.57 \mathrm{Ba}$ & 1.63 & $7.23 \mathrm{Ba}$ & 0.38 \\
\hline \multicolumn{7}{|c|}{ Neutral detergent fiber $(\%)$} \\
\hline $\mathrm{CF}$ & $62.76 \mathrm{Aa}$ & 0.82 & $64.41 \mathrm{Aa}$ & 1.25 & $65.24 \mathrm{Aa}$ & 1.33 \\
\hline NF & $59.96 \mathrm{Aa}$ & 0.77 & $65.85 \mathrm{Ba}$ & 0.53 & $68.22 \mathrm{Ba}$ & 0.88 \\
\hline $2 \times$ & $59.68 \mathrm{Aa}$ & 0.58 & $67.26 \mathrm{Ba}$ & 1.56 & $73.70 \mathrm{Cb}$ & 1.00 \\
\hline \multicolumn{7}{|c|}{ Acid detergent fiber (\%) } \\
\hline $\mathrm{CF}$ & $27.50 \mathrm{Aa}$ & 0.41 & $29.14 \mathrm{Aa}$ & 1.21 & $32.79 \mathrm{Ba}$ & 0.89 \\
\hline NF & $26.30 \mathrm{Aa}$ & 0.70 & $31.77 \mathrm{Ba}$ & 0.30 & $33.49 \mathrm{Bab}$ & 1.41 \\
\hline $2 \times$ & $25.89 \mathrm{Aa}$ & 0.28 & $32.90 \mathrm{Ba}$ & 1.06 & $37.58 \mathrm{Cb}$ & 0.70 \\
\hline \multicolumn{7}{|c|}{ Acid detergent lignin (\%) } \\
\hline CF & $2.65 \mathrm{Aa}$ & 0.18 & $1.64 \mathrm{Ba}$ & 0.10 & $1.69 \mathrm{Ba}$ & 0.20 \\
\hline NF & $2.34 \mathrm{Aa}$ & 0.13 & $1.61 \mathrm{Ba}$ & 0.04 & $1.93 \mathrm{Ba}$ & 0.10 \\
\hline $2 \times$ & $2.25 \mathrm{ABa}$ & 0.23 & $1.92 \mathrm{Aa}$ & 0.16 & $2.51 \mathrm{Bb}$ & 0.13 \\
\hline \multicolumn{7}{|c|}{ Relative feed value (\%) } \\
\hline $\mathrm{CF}$ & $100.07 \mathrm{Aa}$ & 1.77 & $95.73 \mathrm{Aa}$ & 3.08 & $90.45 \mathrm{Aa}$ & 2.77 \\
\hline NF & $106.20 \mathrm{Aa}$ & 2.09 & $90.64 \mathrm{Ba}$ & 1.03 & 85.71 Bab & 2.52 \\
\hline $2 \times$ & 107.18 Aa & 1.36 & $87.66 \mathrm{Ba}$ & 3.11 & $75.31 \mathrm{Cb}$ & 1.69 \\
\hline
\end{tabular}

${ }^{1}$ Standard errors of the mean were calculated from $n=3$ open-top chambers.

${ }^{2}$ Mean values in a row with different upper case letters are different $(P<0.05)$ based on Tukey-adjusted least squares means.

${ }^{3}$ Mean values in a column within a period with different lower case letters are different $(P<0.05)$ based on Tukey-adjusted least squares means.

nutritive quality of managed forage systems (Ashmore and Ainsworth 1995; Wilbourn et al. 1995; Muntifering et al. 2000). By timing a harvest just prior to an acute, predictable $\mathrm{O}_{3}$ episode, range managers could potentially avert damage to the standing crop while decreasing $\mathrm{O}_{3}$ damage on regrowth material.

Few studies have actually quantified losses attributed to ozone pollution in terms of nutritive quality. Selection of plant parts having greater nutritional value is common among browsing herbivores. Bolsinger (1991) observed ornamental milkweed (Asclepias curassavica L.) exposed to elevated $\mathrm{O}_{3}$ and found interaction between concentration and exposure time. They concluded that changes in metabolites could interact with plant nutrition in ways that might alter insect herbivory. We believe that a similar interaction could occur in systems with domestic and wild ruminants as well as other mammalian herbivores. In addition, plants high in defensive compounds (i.e., phenolics) and indigestible material (i.e., lignin) will be less likely to be selected by herbivorous species. Because both native 
Table 4. Nutritive quality values for big bluestem (Andropogon gerardii) and eastern gamagrass (Tripsacum dactyloides) secondary growth exposed to 3 ozone concentrations from 9 June-4 September 2003 and harvested during 2 periods at 30-d intervals from plants cut during the first primary harvest.

\begin{tabular}{|c|c|c|c|c|}
\hline & \multicolumn{2}{|c|}{ Regrowth 1} & \multicolumn{2}{|c|}{ Regrowth 2} \\
\hline & $\bar{x}$ & $\mathrm{SE}^{1}$ & $\bar{x}$ & SE \\
\hline \multicolumn{5}{|c|}{ Eastern gamagrass } \\
\hline \multicolumn{5}{|c|}{ Biomass (g DM/plant) } \\
\hline $\mathrm{CF}$ & $6.42 \mathrm{~A}^{2} \mathrm{a}^{3}$ & 2.90 & $7.52 \mathrm{Aa}$ & 0.16 \\
\hline NF & $8.73 \mathrm{Aa}$ & 1.16 & $6.13 \mathrm{Aa}$ & 0.58 \\
\hline $2 \times$ & $13.80 \mathrm{Aa}$ & 1.21 & $8.60 \mathrm{Aa}$ & 1.22 \\
\hline \multicolumn{5}{|c|}{ Crude protein (\%) } \\
\hline $\mathrm{CF}$ & $15.81 \mathrm{Aa}$ & 2.24 & $10.9 \mathrm{Aa}$ & 1.91 \\
\hline NF & $12.09 \mathrm{Aa}$ & 1.14 & $10.53 \mathrm{Aa}$ & 0.91 \\
\hline $2 \times$ & $11.91 \mathrm{Aa}$ & 0.78 & $9.96 \mathrm{Aa}$ & 1.04 \\
\hline \multicolumn{5}{|c|}{ Neutral detergent fiber (\%) } \\
\hline $\mathrm{CF}$ & $65.89 \mathrm{Aa}$ & 0.29 & $65.09 \mathrm{Aa}$ & 0.97 \\
\hline NF & $68.20 \mathrm{Aa}$ & 1.58 & $64.46 \mathrm{Aa}$ & 1.74 \\
\hline $2 \times$ & $67.46 \mathrm{Aa}$ & 2.02 & $68.26 \mathrm{Aa}$ & 1.24 \\
\hline \multicolumn{5}{|c|}{ Acid detergent fiber (\%) } \\
\hline $\mathrm{CF}$ & $31.42 \mathrm{Aa}$ & 0.86 & $30.57 \mathrm{Aa}$ & 0.86 \\
\hline NF & $33.35 \mathrm{Aa}$ & 0.93 & $31.44 \mathrm{Aa}$ & 1.29 \\
\hline $2 \times$ & $32.91 \mathrm{Aa}$ & 0.80 & $32.94 \mathrm{Aa}$ & 0.32 \\
\hline \multicolumn{5}{|c|}{ Acid detergent lignin (\%) } \\
\hline $\mathrm{CF}$ & $1.93 \mathrm{Aa}$ & 0.07 & $1.72 \mathrm{Aa}$ & 0.15 \\
\hline$N F$ & $2.03 \mathrm{Aa}$ & 0.06 & $1.91 \mathrm{Aa}$ & 0.11 \\
\hline $2 \times$ & $1.78 \mathrm{Aa}$ & 0.12 & $2.33 \mathrm{Aa}$ & 0.15 \\
\hline \multicolumn{5}{|c|}{ Relative feed value (\%) } \\
\hline $\mathrm{CF}$ & $90.97 \mathrm{Aa}$ & 1.34 & $93.09 \mathrm{Aa}$ & 2.30 \\
\hline NF & $85.96 \mathrm{Aa}$ & 2.84 & $93.16 \mathrm{Aa}$ & 3.96 \\
\hline $2 \times$ & $87.44 \mathrm{Aa}$ & 3.37 & $86.25 \mathrm{Aa}$ & 1.78 \\
\hline \multicolumn{5}{|c|}{ Big bluestem } \\
\hline \multicolumn{5}{|c|}{ Biomass (g DM/plant) } \\
\hline $\mathrm{CF}$ & $10.02 \mathrm{~A}^{2} \mathrm{a}^{3}$ & 4.05 & $7.06 \mathrm{Aa}$ & 0.44 \\
\hline$N F$ & $7.98 \mathrm{Aa}$ & 2.89 & $5.03 \mathrm{Aa}$ & 0.39 \\
\hline $2 \times$ & $6.73 \mathrm{Aa}$ & 1.68 & $5.97 \mathrm{Aa}$ & 1.02 \\
\hline \multicolumn{5}{|c|}{ Crude protein (\%) } \\
\hline $\mathrm{CF}$ & $9.40 \mathrm{Aa}$ & 0.78 & $8.11 \mathrm{Aa}$ & 0.69 \\
\hline NF & $9.59 \mathrm{Aa}$ & 0.69 & $8.78 \mathrm{Aa}$ & 0.66 \\
\hline $2 \times$ & $9.75 \mathrm{Aa}$ & 0.84 & $9.52 \mathrm{Aa}$ & 1.36 \\
\hline \multicolumn{5}{|c|}{ Neutral detergent fiber (\%) } \\
\hline $\mathrm{CF}$ & $67.30 \mathrm{Aa}$ & 0.50 & $69.30 \mathrm{Aa}$ & 1.07 \\
\hline NF & $68.76 \mathrm{Aa}$ & 1.09 & $70.28 \mathrm{Aa}$ & 0.45 \\
\hline $2 \times$ & $70.69 \mathrm{Aa}$ & 0.62 & $70.29 \mathrm{Aa}$ & 1.16 \\
\hline \multicolumn{5}{|c|}{ Acid detergent fiber (\%) } \\
\hline $\mathrm{CF}$ & $35.27 \mathrm{Aa}$ & 0.67 & $36.61 \mathrm{Aa}$ & 0.72 \\
\hline NF & $35.33 \mathrm{Aa}$ & 1.01 & $36.90 \mathrm{Aa}$ & 0.41 \\
\hline $2 \times$ & $36.59 \mathrm{Aa}$ & 0.75 & $37.61 \mathrm{Aa}$ & 0.58 \\
\hline
\end{tabular}

Table 4. Continued.

\begin{tabular}{|c|c|c|c|c|}
\hline & \multicolumn{2}{|c|}{ Regrowth 1} & \multicolumn{2}{|c|}{ Regrowth 2} \\
\hline & $\bar{x}$ & $\mathrm{SE}^{1}$ & $\bar{x}$ & SE \\
\hline \multicolumn{5}{|c|}{ Acid detergent lignin (\%) } \\
\hline $\mathrm{CF}$ & $1.64 \mathrm{Aa}$ & 0.05 & $1.67 \mathrm{Aa}$ & 0.18 \\
\hline NF & $1.77 \mathrm{Aa}$ & 0.13 & $2.05 \mathrm{Aa}$ & 0.28 \\
\hline $2 \times$ & $1.82 \mathrm{Aa}$ & 0.10 & $2.06 \mathrm{Aa}$ & 0.17 \\
\hline \multicolumn{5}{|c|}{ Relative feed value (\%) } \\
\hline $\mathrm{CF}$ & $84.91 \mathrm{Aa}$ & 1.05 & $81.13 \mathrm{Aa}$ & 2.02 \\
\hline NF & $83.10 \mathrm{Aa}$ & 2.23 & $79.63 \mathrm{Aa}$ & 0.94 \\
\hline $2 \times$ & $79.52 \mathrm{Aa}$ & 1.45 & $78.94 \mathrm{Aa}$ & 1.77 \\
\hline
\end{tabular}

${ }^{1}$ Standard errors of the mean were calculated from $n=3$ open-top chambers.

${ }^{2}$ Mean values in a row with different upper case letters are different $(P<0.05)$ based on least squares means.

${ }^{3}$ Mean values in a column within a period with different lower case letters are different $(P<0.05)$ based on least squares means.

herbivores and livestock have been shown to select forage species based on a wide variety of criteria (Stephens and Krebs 1986; Robbins 1993; Van Soest 1994), it is critical that we understand how $\mathrm{O}_{3}$ influences nutritive quality of forages.

As intake and rate of passage are limiting factors controlling ruminant digestion, constant biomass production with reduced nutritive value creates a situation whereby the ruminant stomach is filled to capacity without realizing full nutritive potential. Powell et al. (2003) found greater concentrations of fiber fractions and decreased in vitro digestibility in $2 \times$ and $\mathrm{NF}$ than in CF primary growth of sericea lespedeza (Lespedeza cuneata Dumont), resulting in approximately $7 \%$ decline in nutritive quality. Additionally, they found $<2 \%$ decrease in quality of little bluestem (Schizachyrium scoparium Nash), but concluded that both species would be affected enough to decrease utilization by ruminants. They found no difference among treatments in regards to DM yield for primary growth. We found a $30 \%$ reduction in nutritive quality of eastern gamagrass, but found an increase in biomass in periods 2 and 3 , suggesting that ruminants consuming these forages may be receiving less nutrition per unit of biomass consumed than from forages exposed to lower levels of $\mathrm{O}_{3}$.

\section{MANAGEMENT IMPLICATIONS}

While most studies on native species have focused on visible injury, scientists must become increasingly aware of how $\mathrm{O}_{3}$ affects nutritive quality of forages. Total biomass will always be important; however, wildlife and domestic livestock select forages and plant parts based on nutritional quality as well as quantity. Nutritive quality affected by $\mathrm{O}_{3}$ could have ramifications for plant selection by herbivores. By decreasing digestibility and crude protein, $\mathrm{O}_{3}$ could cause shifts in forage selection that could alter plant communities. When land managers select species to plant in areas with elevated $\mathrm{O}_{3}$, our data suggest big bluestem would be an optimal choice over eastern gamagrass. Furthermore, range managers can use information on $\mathrm{O}_{3}$ response of specific forage species by altering their cutting regime to maximize nutritional value while decreasing $\mathrm{O}_{3}$ damage to susceptible species. 
Table 5. Period, treatment, and period $\times$ treatment main effects for big bluestem (Andropogon gerardii) primary growth exposed to 3 ozone concentrations from 9 June-4 September 2003 and harvested during 3 periods at 30-d intervals.

\begin{tabular}{|c|c|c|c|c|c|c|c|c|c|}
\hline & \multicolumn{3}{|c|}{ Period } & \multicolumn{3}{|c|}{ Treatment } & \multicolumn{3}{|c|}{ Period $\times$ treatment } \\
\hline & $\mathrm{df}$ & $F$ & $P$ & df & $F$ & $P$ & df & $F$ & $P$ \\
\hline Biomass (g DM/plant) & 2,10 & 17.24 & $<0.001$ & 2,10 & 0.270 & 0.771 & 2,10 & 0.75 & 0.576 \\
\hline Crude protein (\%) & 2,10 & 35.60 & $<0.001$ & 2,10 & 1.48 & 0.284 & 2,10 & 0.20 & 0.932 \\
\hline Neutral detergent fiber (\%) & 2,10 & 8.38 & 0.007 & 2,10 & 2.15 & 0.179 & 2,10 & 0.31 & 0.865 \\
\hline Acid detergent fiber (\%) & 2,10 & 18.77 & $<0.001$ & 2,10 & 1.85 & 0.219 & 2,10 & 0.73 & 0.592 \\
\hline Acid detergent lignin (\%) & 2,10 & 14.84 & 0.001 & 2,10 & 1.33 & 0.316 & 2,10 & 1.31 & 0.332 \\
\hline Relative feed value (\%) & 2,10 & 14.13 & 0.001 & 2,10 & 2.04 & 0.193 & 2,10 & 0.54 & 0.711 \\
\hline
\end{tabular}

Table 6. Nutritive quality values for big bluestem (Andropogon gerardii) primary growth exposed to 3 ozone concentrations from 9 June4 September 2003 and harvested during 3 periods at 30-d intervals.

\begin{tabular}{|c|c|c|c|c|c|c|}
\hline & \multicolumn{2}{|c|}{ Period 1 (30 d) } & \multicolumn{2}{|c|}{ Period 2 (60 d) } & \multicolumn{2}{|c|}{ Period $3(90 \mathrm{~d})$} \\
\hline & $\bar{x}$ & $\mathrm{SE}^{1}$ & $\bar{x}$ & SE & $\bar{x}$ & SE \\
\hline \multicolumn{7}{|c|}{ Biomass (g DM/plant) } \\
\hline $\mathrm{CF}$ & $1.16 \mathrm{~A}^{2} \mathrm{a}^{3}$ & 0.32 & $10.35 \mathrm{ABa}$ & 4.50 & $21.20 \mathrm{Ba}$ & 4.70 \\
\hline NF & $0.82 \mathrm{Aa}$ & 0.22 & $9.67 \mathrm{ABa}$ & 1.85 & $20.05 \mathrm{Ba}$ & 4.32 \\
\hline $2 \times$ & $0.95 \mathrm{Aa}$ & 0.26 & $12.65 \mathrm{Aa}$ & 5.51 & $12.93 \mathrm{Aa}$ & 4.24 \\
\hline \multicolumn{7}{|c|}{ Crude protein (\%) } \\
\hline $\mathrm{CF}$ & $15.43 \mathrm{Aa}$ & 1.43 & $10.70 \mathrm{ABa}$ & 1.18 & $8.00 \mathrm{Ba}$ & 0.89 \\
\hline NF & $14.76 \mathrm{Aa}$ & 0.22 & $9.61 \mathrm{ABa}$ & 0.87 & $5.88 \mathrm{Ba}$ & 0.92 \\
\hline $2 \times$ & $14.25 \mathrm{Aa}$ & 0.74 & $10.72 \mathrm{ABa}$ & 1.70 & $6.90 \mathrm{Ba}$ & 0.81 \\
\hline
\end{tabular}

Neutral detergent fiber (\%)

$\begin{array}{lllllll}\mathrm{CF} & 65.75 \mathrm{Aa} & 0.06 & 65.68 \mathrm{Aa} & 0.81 & 71.92 \mathrm{Aa} & 2.69 \\ \mathrm{NF} & 66.46 \mathrm{Aa} & 0.56 & 67.67 \mathrm{Aa} & 0.63 & 72.36 \mathrm{Aa} & 1.10 \\ 2 \times & 66.04 \mathrm{Aa} & 0.69 & 67.42 \mathrm{Aa} & 1.74 & 69.46 \mathrm{Aa} & 1.56\end{array}$

Acid detergent fiber (\%)

$\begin{array}{lllllll}\mathrm{CF} & 30.54 \mathrm{Aa} & 0.13 & 32.59 \mathrm{ABa} & 1.25 & 39.21 \mathrm{Ba} & 2.46 \\ \mathrm{NF} & 30.69 \mathrm{Aa} & 0.86 & 35.66 \mathrm{Aa} & 0.42 & 39.69 \mathrm{Aa} & 1.68 \\ 2 \times & 30.75 \mathrm{Aa} & 1.21 & 34.80 \mathrm{Aa} & 1.76 & 36.62 \mathrm{Aa} & 1.74\end{array}$

Acid detergent lignin (\%)

$\begin{array}{lllllll}\mathrm{CF} & 1.94 \mathrm{ABa} & 0.07 & 1.40 \mathrm{Aa} & 0.09 & 2.83 \mathrm{Ba} & 0.40 \\ \mathrm{NF} & 1.91 \mathrm{Aa} & 0.07 & 1.67 \mathrm{Aa} & 0.21 & 2.71 \mathrm{Aa} & 0.19 \\ 2 \times & 1.96 \mathrm{Aa} & 0.10 & 1.68 \mathrm{Aa} & 0.15 & 1.98 \mathrm{Aa} & 0.16\end{array}$

Relative feed value (\%)

CF

NF

$\begin{array}{llllll}92.12 \mathrm{Aa} & 0.21 & 90.01 \mathrm{Aa} & 2.23 & 75.86 \mathrm{Aa} & 5.16\end{array}$

$91.00 \mathrm{Aa} \quad 1.6984 .04 \mathrm{Aa} \quad 1.22 \quad 74.63 \mathrm{Aa} \quad 2.83$

$2 \times$

$\begin{array}{llllll}91.52 \mathrm{Aa} & 2.31 & 85.49 \mathrm{Aa} & 3.98 & 81.03 \text { Аa } & 3.70\end{array}$

${ }^{1}$ Standard errors of the mean were calculated from $n=3$ open-top chambers.

${ }^{2}$ Mean values in a row with different upper case letters are different $(P<0.05)$ based on least squares means.

${ }^{3}$ Mean values in a column within a period with different lower case letters are different $(P<0.05)$ based on least squares mean.

\section{LITERATURE CITED}

Adams, R. M., J. D. Glyer, S. L. Johnson, and B. A. McCarl. 1989. A reassessment of the economic effects of ozone on US agriculture. Journal of the Air Pollution Control Association 39:960-968.

Adams, R. M., J. D. Glyer, and B. A. McCarl. 1988. The NCLAN economic assessment: approach, findings and implications. In: W. W. Heck, O. C. Taylor, and D. T. Tingey [EDS.]. Assessment of crop loss from air pollutants. New York: Elsevier Applied Science. p 473-504.

[AOAC] Association of Official Analytical Chemists. 1995. Official methods of analysis of the Association of Official Analytical Chemists. 15th ed. Washington, DC: AOAC.

Ashmore, M. R., And N. Ainsworth. 1995. The effects of ozone and cutting on the species composition of artificial grassland communities. Functional Ecology 9:708-712.

Ball, D. M., C. S. Hoveland, and G. D. LaAcefield. 2002. Southern forages: Modern concepts for forage crop management. 3rd ed. Norcross, GA: Potash and Phosphate Institute. 322 p.

Best, L. B., H. I. Campa, K. E. Kemp, R. J. Robel, M. R. Ryan, J. A. Savidge, J. Weeks, P. HaRmon, and S. R. Wintersteln. 1997. Bird abundance and nesting in CRP fields and cropland in the Midwest: a regional approach. Wildlife Society Bulletin 25:864-877.

Bolsinger, M., M. E. Lier, D. M. Lansky, and P. R. Hughes. 1991. Influence of ozone air pollution on plant-herbivore interactions. Part 1: biochemical changes in ornamental milkweed (Asclepias curassavica L.; Asclepiadaceae) induced by ozone. Environmental Pollution 72:69-83.

Byington, E. K., And R. D. Child. 1981. Forages from the world's forested land for ruminant animal production. In: R. D. Child and E. K. Byington [EDS.]. Potential of the world's forages for ruminant animal production. Morrilton, AR: Winrock International. p 93-107.

Chameides, W. L., and E. B. Cowling. 1995. The state of the Southern Oxidants Study (SOS): Policy-relevant findings in ozone pollution research, 1988-1994. Raleigh, NC: College of Forestry, North Carolina State University. 94 p.

Chameides, W. L., P. S. Kasibhatla, J. Yienger, and H. Levy II. 1994. Growth of continental-scale metro-agro-plexes, regional ozone pollution, and world food production. Science 264:74-77.

Chappelka, A. H., and L. J. Samuelson. 1998. Ambient ozone effects on forest trees of the eastern United States: a review. New Phytologist 139:91-108.

Chappelka, A. H., and D. J. Wergowske. 1994. Air pollution injury observed in Talladega National Forest. Alabama Agricultural Experiment Station Highlights in Agriculture Research 41:9.

FuHRER, J. 1997. Ozone sensitivity of managed pastures. In: P. N. Cheremisinoff [ED.]. Ecological issues and environmental impact assessment. Houston, TX: Gulf Publishing Company. p 681-706.

Giuliano, W. M., and S. E. Daves. 2002. Avian response to warm-season grass use in pasture and hayfield management. Biological Conservation 106: $1-9$.

Heagle, A. S., L. W. Kress, P. J. Temple, R. J. Kohut, J. E. Miller, and H. E. HegGestad. 1988. Factors influencing ozone dose-yield response relationships in open-top field chamber studies. In: W. W. Heck, O. C. Taylor, and D. T. Tingey [EDS.]. Assessment of crop loss from air pollutants. New York, NY: Elsevier Applied Science. p 141-179.

Heagle, A. S., R. B. Philbeck, R. E. Ferrell, and W. W. Heck. 1989. Design and performance of a large, field exposure chamber to measure effects of air quality on plants. Journal of Environmental Quality 18:361-368.

Kängasjarvi, J., J. Talvinen, M. Ultrianen, and R. Karajalainen. 1994. Plant defense systems induced by ozone. Plant, Cell, and the Environment 17:783-794.

Karlsson, G. P., G. Sellden, L. Skarby, and H. Pleijel. 1995. Clover as an in- 
dicator plant for phytotoxic ozone concentrations-Visible injury in relation to species, leaf age and exposure dynamics. New Phytologist 129: 355-365.

Krupa, S. V., and W. J. Manning. 1988. Atmospheric ozone: formation and effects on vegetation. Environmental Pollution 50:101-137.

Krupa, S. V., R. Muntifering, and A. Chappelka. 2004. Effects of ozone on plant nutritive quality characteristics for ruminant animals. The Botanica 54:129-140.

Lefohn, A. S., S. V. KRUPA, and D. Winstanley. 1990. Surface ozone exposures measured at clean locations around the world. Environmental Pollution 63 189-224.

Linn, J. G., AND N. P. Martin. 1989. Forage quality tests and interpretation. Minneapolis, MN: University of Minnesota Extension Service. $12 \mathrm{p}$.

Manning, W. J. 2003. Detecting plant effects is necessary to give biological significance to ambient ozone monitoring data and predictive ozone standards. Environmental Pollution 126:375-379.

MiLleR, J. E. 1988. Effects on photosynthesis, carbon allocation, and plant growth associated with air pollutant stress. In: W. W. Heck, 0. C. Taylor, and D. T. Tingey [EDS.]. Assessment of crop loss from air pollutants. London, New York: Elsevier Applied Science. p 287-314.

Muntifering, R. B., D. D. Crosby, M. C. Powell, and A. H. Chappelka. 2000. Yield and quality characteristics of bahiagrass (Paspalum notatum) exposed to groundlevel ozone. Animal Feed Science and Technology 84:243-256.

[NCEA] National Center for Environmental Assessment. 1996. Air quality criteria for ozone and related photochemical oxidants. Research Triangle Park, NC: National Center for Environmental Assessment Office of Research and Development, U.S. Environmental Protection Agency. 821 p.

PleiJel, H., And H. Danielsson. 1997. Growth of 27 herbs and grasses in relation to ozone exposure and plant strategy. New Phytologist 135:361-367.

Pleijel, H., G. P. Karlsson, E. Sild, H. Danielsson, L. Skärby, and G. Selldén. 1996. Exposure of a grass-clover mixture to ozone in open-top chambers-effects on yield, quality and botanical composition. Agriculture, Ecosystems \& Environment 59:55-62.

Powell, M. C., R. B. Muntifering, J. C. Lin, and A. H. Chappelka. 2003. Yield and nutritive quality of sericea lespedeza (Lespedeza cuneata) and little bluestem
(Schizachyrium scoparium) exposed to ground-level ozone. Environmental Pollution 122:313-322.

RoBBins, C. T. 1993. Wildlife feeding and nutrition. 2nd ed. San Diego, CA: Academic Press. 352 p.

Rohweder, D. A., R. F. Barnes, and N. Jorgensen. 1978. Proposed hay grading standards based on laboratory analyses for evaluating quality. Journal of Animal Science 47:747-759.

RUNECKLES, V. C., AND S. V. KRUPA. 1994. The impact of UV-B radiation and ozone on terrestrial vegetation. Environmental Pollution 83:191-213.

SAS InStitute. 1990. SAS/STAT User's Guide, Release 6.04. Cary, NC: SAS Institute. $1686 \mathrm{p}$.

Stephens, D. W., AND J. R. KReBs. 1986. Foraging theory. Princeton, NJ: Princeton University Press. $247 \mathrm{p}$.

Stubbendieck, J. L., S. L. Hatch, And C. H. Butterfield. 1997. North American range plants. 5th ed. Lincoln, NE: University of Nebraska Press. 501 p.

Temple, P. J., O. C. TayloR, and L. F. Benoit. 1985. Cotton yield responses to ozone as mediated by soil moisture and evapotransporation. Journal of Environmental Quality 14:55-60.

US EPA. 2001. Latest finds on national air quality: 2000 status and trends. Report EPA 454/K-01-002.

Van Soest, P. J. 1994. Nutritional ecology of the ruminant. 2nd ed. Ithaca, NY: Cornell University Press. 476 p.

Van Soest, P. J., J. B. Robertson, and B. A. Lewis. 1991. Methods for dietary fiber, neutral detergent fiber, and nonstarch polysaccharides in relation to animal nutrition. Journal of Dairy Science 74:3583-3597.

Vingarzan, R. 2004. A review of surface $\mathrm{O}_{3}$ backgound levels and trends. Atmospheric Environment 38:3431-3442.

Volin, J. C., P. B. Reich, And T. J. Givisish. 1998. Elevated carbon dioxide ameliorates the effects of ozone on photosynthesis and growth: species respond similarly regardless of photosynthetic pathway or plant functional group. New Phytologist 138:315-325.

Wilbourn, S., A. W. Davison, and J. H. Ollerenshaw. 1995. The use of an unenclosed field fumigation system to determine the effects of elevated ozone on a grass clover mixture. New Phytologist 129:23-32. 